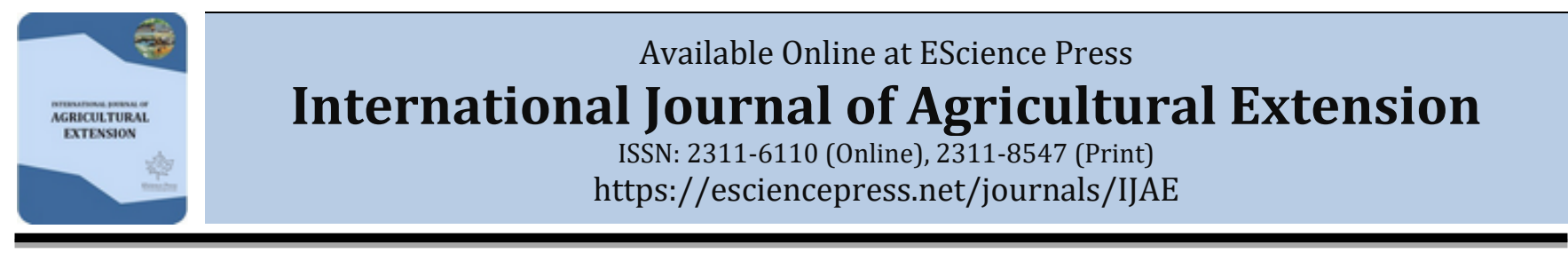

\title{
ASSESSMENT OF MULTI-ACTOR STAKEHOLDERS' ROLE IN CONFLICT RESOLUTION IN PUNJAB, PAKISTAN
}

\author{
Sohaib Usman*, Aqeela Saghir, Khalid Mahmood Ch., Ijaz Ashraf, Aisha Rani \\ Institute of Agricultural Extension and Rural Development, University of Agriculture Faisalabad.
}

*Corresponding Author Email: sohaibusmancheema174@gmail.com

\section{A B S T R A C T}

This study was conducted in tehsil Naushera Virkan of district Gujranwala, Punjab Pakistan with the emphasis on assessment of multi-actors roles in conflict resolution among rural people. Total 75 respondents selected through snowball sampling technique were interviewed face to face followed by two focus group discussions with the potential elite in area. The quantitative data were analyzed using Statistical Package for Social Sciences (SPSS) and qualitative data were analyzed through content analysis approach. For quantitative data, descriptive statistics (percentage, mean, standard deviation) were applied for the meaningful interpretation of data. Findings indicated that burning of crops $(\overline{\mathrm{x}}=3.90)$, loan on agricultural lands $(\overline{\mathrm{x}}=3.89)$, inter-cast marriage system $(\overline{\mathrm{x}}=3.87)$ and water distribution $(\overline{\mathrm{x}}=3.76)$ were foremost reasons of conflicts as perceived by the respondents. Perceived conflicts had more impacts on the distribution of income $(\overline{\mathrm{x}}=4.00)$, lack of unity $(\overline{\mathrm{x}}=3.92)$ and farm production $(\overline{\mathrm{x}}=3.91)$. Informal Judicial System (Panchayat) ( $\overline{\mathrm{x}}=4.18$ ), Local leaders (Numberdar) (4.10), Elder family members/neighbours $(\overline{\mathrm{x}}=4.00)$, Local police station (Thana) $(\overline{\mathrm{x}}=3.95)$ and Politicians $(\overline{\mathrm{x}}=3.94)$ were the key stakeholders playing role in conflicts resolution.

Keywords: Conflicts, causes, effects, conflict resolution.

\section{INTRODUCTION}

Conflict is a natural fact usually occurring in routine life among people residing in society. Societal conflicts are generally well-defined as disagreement among people, between two personalities and a group of individuals depending on opposite benefits, differing characteristics and unlikely approaches (Schellenberg, 2006). The number of factors including assets, influence, effort and status ignite the different types of conflicts. Fundamentally, it is a fight among people and group of individuals concerned to varying problems like narrowing assets, status in society, supremacy and repute related disputes pressurizing two people or groups to pursue their actions which may be contradictory to each other and result into a conflict. Therefore, the term conflict can be extended broadly from the individual level to the group level and maybe worsen to two nations or two states level. Potentially, the conflict may rise rivalries (Galtung, 2006). According to Ekong (2003) conflict is a system of societal dealings where the involved individuals strive to possess rare incentives by eradicating and failing their competitors. Folger et al. (2009) argued conflict as a contact of mutually dependent individuals perceiving opposing objectives and intervention from each other in attaining those aims. Conflict is the tussle for domination or control of an individual or group of individuals in such a manner as to conquer or even exclude the rival (Gyong, 2007). Yishai (2002) has identified that conflict was a result of negative behaviour. He arbitrated that, ideological differences between two or more people gave birth to the conflicts. According to Haro et al. (2005) conflict has a specific context. It could be based on personal relationships, property, interest-based and moral values. Glasius (2004) identified that dispute was the main reason for the conflict. He further maintained that conflict needs proper resolution and dialogue, understanding and mutual cooperation for the development of the social sector with the active involvement of different stakeholder was the foremost 
and cost-effective solution in this regard. The differences in micro-level emerge for a meagre stance and can be overcome easily. Conflicts arising from the impacts of the dam on the local population and territory and steps to resolve some of them are identified. These impacts relate to unfair land acquisition, improper displacement, inadequate compensation, resettlement and future livelihoods (Sabir et al., 2017). Pakistan is an agrarian country where agriculture contributes $18.5 \%$ to country's Gross Domestic Product (GDP) and provides $38.5 \%$ employment to the national labour force and more than half of the population is directly and indirectly dependent upon agriculture. In different media sources, various conflicts are reported even claiming deaths and suicides of the farmers in particular. For instance, a dispute on water theft costs farmer life and feud over land grabbing and acquisition cost farmers their precious lives. However, no empirical evidence exists to report this critical issue. Few studies such as Iqbal (2004), Magsi \& Torre (2012) and Haider et al. (2017) had narrowly mentioned that conflicts had impacts on the socio-economic development of the people in Pakistan. Iqbal (2004) has reported that constriction of dams dislocated people and conflicts among people emerged whereas Magsi \& Torre (2012) unveiled political favouritism as a reason for rising conflicts. Haider et al. (2017) concluded that conflicts had a significant impact on the income of the farmers growing tomato crop. The findings explained, pertinent to conflicts mobility of the farmers was restricts, farmers had limited access to cultivable land, irrigation facilities, and input and output channels. Thus, the production went down earning a minor margin to the growers.

Considering the dearth of available information an important, this study was planned to examine the role of multi-actors in order to tackle the conflicts being faced by the people. This study also examined the different impacts of the conflicts as perceived by the respondents. In the end, this study attempted to reveal those sources that people were relying on for conflict resolution.

\section{METHODOLOGY}

This study was conducted in Naushera Virkan a subdistrict of district Gujranwala in Punjab province of Pakistan. It is situated in northern Punjab and is known as the city of wrestlers and is quite famous for its food. The majority of its population lives in rural areas and mainly earns their livelihood through agriculture and other allied disciplines. It has 9 Markaz, 97 Union
Councils, 800 Villages with a total area of 892067 acres, out of which 783339 acres are cultivated. Rice, Wheat and Sugarcane are the main crops grown in the district. The source of irrigation is perennial and non-perennial canals supplemented by tub wells. Besides, Jawar, Bajra, Mash, Moong, Masoor, Gram, Maize, Tobacco, Oil Seed such as Rape/Mustard and sunflower are also grown in minor quantities in the district. Guavas and Citrus are the main fruits grown in the district. Besides, Peaches, Jaman and Banana are also grown in minor quantities in the district. It indicates a worth mentioning the scope of agriculture in the district.

Sample Selection: For the selection of sample multistage sampling technique was adopted. On the first stage, district Gujranwala was selected purposively. Gujranwala City, Gujranwala Saddar, Wazirabad, Kamonki and Naushera Virkan are the 5 sub-districts of the Gujranwala. On the second stage, of the five subdistricts, Naushera Virkan was selected at random. On the third stage, through snowball sampling technique 75 respondents were selected. Respondents were scattered in the area and there was no record of the conflicts in the district to serve as the sampling frame. Polit-O'Hara \& Beck (2006) has stated that the snowball technique is an efficient and cost-effective method to access people who would otherwise be very difficult to find. Hejazi (2006) maintained that the snowball method is useful for locating those people who are not willing to reveal their identities.

Data Collection: Data collection process initiated with the development of the questionnaire well inline to the study objectives. The questionnaire was validated and pre-tested prior final data collection and later administered through a face to face interview technique.

\section{Focus groups Discussion (FGD)}

Two focus groups were organized in the study area and each focus group consisted of 10-12 respondents. First FGD was maintained with experts from Agriculture Extension Department, Government of Punjab, functional in the district for the technical backstopping of farmers and few members from Non-Governmental Organizations (NGOs) mainly focused on peacebuilding through conflict resolution. The second focus group was organized with Local leaders (Numberdar), local politicians, social workers and contact farmers. An interview guide was prepared to conduct focus groups for in-depth analysis. Data were recorded electronically and the duration of each focus group was between 60-90 minutes. 
Data Analysis: Regarding data analysis, quantitative data were analyzed using Statistical Package for Social Sciences (SPSS). Qualitative data were analyzed through content analysis method. The qualitative responses were used for the validation of quantitative results.

\section{RESULTS AND DISCUSSION}

Table 1 shows that $32 \%$ of the respondents were of less than 35 years' age and one fourth $(25.3 \%)$ were aged between 36-50 years. About $43 \%$ of the respondent were of more than 50 years. Of the total respondents, $40 \%$ were illiterate and $60 \%$ were literate. Among literates, $32 \%$ had a middle level of education (8 years of schooling) whereas one in ten respondents had the highest level of education (more than 10 years of schooling). Greater than half (56\%) were small farmers followed by 29.3 and $14.7 \%$ medium and large farmers respectively. Tenancy status indicated 53.3, 26.7 and $20 \%$ owners, owner-cum-tenants and tenants respectively. Regarding annual income, $41.3 \%$ were earning 0.2 million annually. About $31 \%$ had to earn between 0.2-0.4 million followed by $28 \%$ who had earnings of more than 0.4 million in a year.

Table 1. Socio-economic characteristics of respondents.

\begin{tabular}{|c|c|c|}
\hline Socio-economic attributes & Frequency & Percentage \\
\hline \multicolumn{3}{|c|}{ Age (in years) } \\
\hline Up to 35 & 24 & 32.0 \\
\hline$>36-50$ & 19 & 25.3 \\
\hline Above 50 & 32 & 42.7 \\
\hline \multicolumn{3}{|c|}{ Education } \\
\hline Illiterate & 30 & 40.0 \\
\hline Below Middle & 24 & 32.0 \\
\hline Metric & 13 & 17.3 \\
\hline Above Metric & 8 & 10.7 \\
\hline \multicolumn{3}{|c|}{ Size of land holding (acres) } \\
\hline Small farmers $(<12)$ & 42 & 56.0 \\
\hline Medium farmers (12-25) & 22 & 29.3 \\
\hline Large farmers $(>25)$ & 11 & 14.7 \\
\hline \multicolumn{3}{|c|}{ Tenancy status } \\
\hline Owner & 40 & 53.3 \\
\hline Owner-cum-tenant & 20 & 26.7 \\
\hline Tenant & 15 & 20.0 \\
\hline \multicolumn{3}{|c|}{ Annual income (PKR) } \\
\hline Up to 200000 (0.2 millions) & 31 & 41.3 \\
\hline $200001-400000$ (0.2-0.4 millions) & 23 & 30.7 \\
\hline Above 400000 (more than 0.4 million) & 21 & 28.0 \\
\hline Total & 75 & 100.0 \\
\hline
\end{tabular}

Table 2. Distribution of the respondents according to the different conflicts faced and perceived by the respondents.

\begin{tabular}{lcc}
\hline Reason of conflicts & Mean \pm Standard deviation & Rank order \\
\hline Burning of crops & $3.90 \pm .831$ & 1 \\
Loan on agricultural land & $3.89 \pm .685$ & 2 \\
Inter cast marriage system & $3.87 \pm .672$ & 3 \\
Water distribution at the farm level & $3.76 \pm .761$ & 4 \\
Crop destroyed by the animals & $3.70 \pm .812$ & 5 \\
Passage way among agriculture land & $3.67 \pm .648$ & 6 \\
\hline
\end{tabular}


Table 2 describes the different conflicts faced and perceived by the respondents. According to the data burning of crops got rank 1st with mean and standard

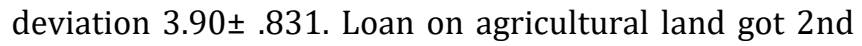
rank with mean $3.89 \pm .685$. Inter cast marriage system and Water distribution at farm level were ranked 3rd and 4th with mean and standard deviation of $3.87 \pm$ $.672,3.76 \pm .761$. Crop destroyed by the animals and Passage way among agriculture land were ranked 5th and 6th position with mean $3.70 \pm .812,3.67 \pm .648$.

As described in the focus discussion that most of the conflicts in their area happened due to the water distribution at farm level because at the farm level there is no proper distribution system to manage the waterrelated issues. Land measurement corruption among two parties is also the significant issues at farm mostly patwari (land registrar) also involved in the conflict among two conflicted farmers because they also involve in corruption and demand for money from one side that becomes the reason of conflict among both parties. The result of this table is less or more similar to the (Nformi, 2014) who discussed that the inter cast marriage system and water distribution at the farm level is the main causes of farm conflicts.

Table 3. Perceived effects of conflict on farmer's families.

\begin{tabular}{lcc}
\hline Holistic effects of conflicts & Mean \pm Standard deviation & Rank order \\
\hline Distribution of income & $4.00 \pm 0.764$ & 1 \\
Lack of unity & $3.92 \pm 0.749$ & 2 \\
Farm production & $3.91 \pm 0.839$ & 3 \\
Influence family relations & $3.90 \pm 0.930$ & 4 \\
Social relationship & $3.89 \pm 0.897$ & 5 \\
Wastage of money and time & $3.89 \pm 0.843$ & 6 \\
Extra Expensive & $3.82 \pm 0.691$ & 7 \\
Judicial cases & $3.80 \pm 0.765$ & 8 \\
Sickness & $3.76 \pm 0.831$ & 9 \\
Family break up & $3.76 \pm 0.764$ & 10 \\
Mental Depression & $3.72 \pm 0.723$ & 11 \\
Child labour & $3.71 \pm 0.717$ & 12 \\
Murder & $3.69 \pm 0.738$ & 13 \\
Child education & $3.65 \pm 0.790$ & 14 \\
Daily routine life & $3.63 \pm 0.653$ & 15 \\
\hline
\end{tabular}

Table 3 shows the prominent effect of conflicts and distribution of income got $1^{\text {st }}$ rank having mean and standard deviation $4.00 \pm 0.764$. This implies that respondents were not able to distribute their income injudicious way pertaining to various conflicts. In equal distribution can originate more conflicts like the high degree of inequality of wealth and income was considered responsible for the civil war (Gurr, 1970, Wickham-Crowley, 1992). Lack of unity ranked at $2^{\text {nd }}$ with mean $3.92 \pm 0.749$ because once the conflicts prevailed respondents were perceived to lose unity among groups. Respondents also perceived that conflicts had an impact on their farm production and was ranked at $3^{\text {rd }}$ with mean $3.91 \pm 0.839$. One of the respondent commented:

"I had a case in court regarding the land dispute and I have invested a lot on my case. I didn't get any decision yet my expenses have become doubled. I was not able to take up my farm operations and failed to invest in my farm as per need".

Respondents further opined that the conflicts have impacted our family relations had ranked $4^{\text {th }}$ with mean $3.90 \pm 0.930$. Apart from that, the respondent witnessed the huge loss of resources such as social relationship ranked $5^{\text {th }}$ with mean $3.89 \pm 0.897$ and money and time ranked $6^{\text {th }}$ had mean $3.89 \pm 0.843$. One of the key informant, very old in age reminded us about past life. He augmented that;

"It was a time when we people used to sit all together and share each other's problem. We were successful in producing the best solutions 
but now the time has changed, people have changed and the way of living has changed. Each individual has started to prefer filing a case in a court against the other". In result, the conflicts are increasing, and people are dividing at pace.

Extra Expensive and Judicial cases were also perceived as an impact of the conflicts ranked at $7^{\text {th }} 8^{\text {th }}$ with mean $3.82 \pm 0.691,3.80 \pm 0.765$. Though, filing a case was not reported beneficial by the respondents except wastage of time and resources. Various other impacts such as sickness, family break ups, mental depression and child labour were ranked $9^{\text {th }}, 10^{\text {th }}, 11^{\text {th }}$ and $12^{\text {th }}$ with mean $3.76 \pm 0.831,3.76 \pm 0.764,3.72 \pm 0.723$ and $3.71 \pm 0.717$ respectively. Murder, impact on education and daily routine life were also perceived as an important impacts due to persisting conflicts and were ranked 13th, 14th, 15 th with mean and S.D 3.69 $\pm 0.738,3.65 \pm 0.790$ and 3.63 \pm 0.653 . Siddik et al. (2018) had reported that conflicts resulted in financial loss, hampered social status, and broke the relationship between plaintiff and defendant.

Table 4. Role of the multi actor of the society in conflict resolution as perceived by respondents.

\begin{tabular}{lcc}
\hline Stakeholders & Mean \pm Standard deviation & Rank order \\
\hline Informal Judicial System (Panchayat) & $4.18 \pm 0.695$ & 1 \\
Local leaders (Numberdar) & $4.10 \pm 0.730$ & 2 \\
Elder family members/neighbours & $4.00 \pm 0.707$ & 3 \\
Local police station (Thana) & $3.95 \pm 0.740$ & 4 \\
Politicians & $3.94 \pm 0.808$ & 5 \\
Social Workers & $3.89 \pm 0.627$ & 6 \\
Headmaster & $3.81 \pm 0.833$ & 7 \\
Middle man & $3.50 \pm 1.00$ & 8 \\
Agriculture extension worker \& staff & $3.40 \pm 0.910$ & 9 \\
\hline
\end{tabular}

Table 4 shows that informal judicial system was perceived more active in resolving issues of the people was ranked 1st $(\bar{x}=4.18 / 5.00)$. Usually, this informal judicial system is named as "Panchayat". In Khyber Pakhtun Khawa, this system is known as Jirga and in Punjab, Sindh and Baluchistan the term Panchayat is widely used. Under this system, the decision is made on the mutual consensus of Panchayat mainly made in consideration of values, norms and expectations (Shinwari, 2015). Respondents perceived that the Panchayat had a great role in conflicts resolution. Roder (2012) had reported that indigenous courts, councils of elders, and similar traditional authorities play a central role in the resolution of disputes. Qu \& Cheung (2012) had claimed that local informal judicial system stays accessible to the poorer and disadvantaged groups and has a tremendous potential of quick justice.

Local leaders (Numberdar) got $2^{\text {nd }} \operatorname{rank}(\overline{\mathrm{x}}=4.10 / 5.00)$, Elder family members/neighbours $3^{\text {rd }}(\bar{x}=4.00 / 5.00)$, Local police station (Thana) was ranked $4^{\text {th }}$ $(\bar{x}=3.95 / 5.00)$, Politicians $5^{\text {th }}(\bar{x}=3.94 / 5.00)$, social workers $6^{\text {th }} \quad(\bar{x}=3.89 / 5.00)$. While the role of Headmaster, Middle man and Agriculture extension worker \& staff were also involved in conflict resolutions as perceived by the respondents were ranked $7^{\text {th }}, 8^{\text {th }}$ and $9^{\text {th }}$ position with mean value $(\bar{x}=3.81 / 5.00)$, $(\bar{x}=3.50 / 5.00)$ and $(\bar{x}=3.40 / 5.00)$. According to the respondents, their major role was mediating between the conflicted groups. The mediation saves time and serves quick justice to the affected group. Mehmood \& Chaudhry (2015) had apprised the mediation process being quick and source of timely justice. Mediation is a historical diplomatic action to resolve the dispute between the two parties (Chaudhry et al., 2014). The mediator stays neutral in the entire process of justice (Walker et al., 2002; Maturoa et al., 2010). Apart from that, Imam masjid, agriculture extension field staff, local police stations and head of schools were reported to be mediating the conflicts. Agricultural Extension is being viewed as a potential sector to mediate among conflictprone people. Ani et al. (2015) have identified that conflicts had impacts overextension advisory services delivery, thus being non-formal education providers and facilitators they would have to play a role of mediator as well. Robertson \& Olson (2012) had reported that agricultural extension can assist people to acquire more 
knowledge, resources and services that will definitely escalate their productivity, wellbeing and resolution to conflicts.

Focus Group Discussions (1st): The focus group with the experts from agriculture extension department and members from the NGOs summarized that conflicts had multidimensional impacts on the rural people and their families. Conflicts considerably impacted the routine life of people as they had weakened their social terms. The staff from agriculture extension department specifically emphasized on farm families and viewed, with a conflict in their lives they wouldn't be able to harvest potential yield. Due to conflicts, some farmers cannot pay focus on his farm. Once he had court cases, he remains to compel to invest here rather on his farm development. He has no proper time to manage his field activities i.e. sowing of the crop at the proper time, irrigation, harvesting and other activities at farm level. Farm production will definitely reduce due to improper management of the field. This reduction in production accentuates the reduction in return which is inevitable to sustain livelihoods of their families. In result, another conflict within a family emerge. Members from the NGOs summarized that conflicts influence an entire life structure of the people. Family relationships get serious impact and their social contacts reduce drastically. A conflicting individual can never be able to maintain his relations, commitments and social status. The members summed up that the conflicts in a family hinder the educational opportunity for their children and obstacle the marriages of girls in particular. How a boy from the peaceful family will tie a knot with the girl belonging to a conflicting family? This is a great matter of concern for those who are involved in a conflict situation and do not seek mediation.

Focus Group Discussion (2nd): Local leaders (Numberdars, Local politicians, social workers and contact farmers were the members of focus group discussions. The major questions asked were the impacts of conflicts in a society and what role they are playing in conflict resolution. An entire group of members agreed that conflicts have significant implications over the entire society and the timely removal of the conflicts was inevitable. The members opined, in a rural setting major source of conflict were land, water, trespassing, inter cast marriages etc. Members were happy to say they are resolving most of the cases. They termed their major role a mediation between two parties. Politicians, panchayat, local leaders and progressive farmers, all they have prestige position in the society and people have a regard for them. Therefore, they were able in mediating many of the cases. However, regarding land conflicts, people prefer to file a case in court where they get nothing except wastage of time and resources. The judicial system of Pakistan is very slow and a poorer hardly gets justice timely. On the contrary, the informal judicial system headed by Panchayat gives access to poorer and underprivileged to get quick justice. Politicians were aware of the sluggish judicial system in Pakistan and they were also involved in mediating between two parties. However, one of the politicians stated,

"Individual who voted for me used to visit me for the mediation, infect my doors are open for the people of the area. Whoever voted for me or not, I am here to serve them as I am their representative.

The political representatives indicated their hefty involvement in resolving water distribution and land grabbing conflicts.

\section{CONCLUSIONS AND RECOMMENDATIONS}

This study concludes that people involved in the conflicts were probably of middle age and middle income, illiterate and small farmers. Among various reasons of conflicts, burning of crops, loan on agricultural land, inter cast marriage system and water distribution at farm level were prominent. It can be said that the reason for conflicts was ordinary but resulting in loss of extraordinary. For instance, routine life was disturbed, family relations were under influence, wastage of money and time, and mental depression was persisting common among people involved in conflicts. The findings of Focus Group Discussions confirmed that conflicts were aroused just for nothing and people wouldn't understand the impact that it could portray on their life. They acclaimed, pertaining to conflicts within society people were not focused on their lives but were more concerned with others. Regarding conflict resolution, the informal judicial system (local panchayat), numberdar, police stations and politicians were prominent in playing their role. However, institutional and social workers role in this regard was found poor.

This study urges a special focus by the government institutions and social worker associations to raise the issues and persuade people to avoid conflict 
involvement and opt peace process for mutual synergistic development. Motivational sessions, training and seminars arranged by the concerned institutions could be harness better outcomes in the wake of changing people's minds positively.

\section{ACKNOWLEDGEMENTS}

We are thankful to all the participants such as political representatives, extension field staff, social workers and local leaders for their support and active participation in the process of data discussion. We are grateful to the Higher Education Commission, Pakistan for the funding.

\section{REFERENCES}

Ani, A. O., J. U. Chikaire, E. I Ogueri. \& J. O. Orusha. (2015). Effects of Communal Conflicts on Agricultural Extension Services Delivery in Imo State, Nigeria. Global Journal of Biology, Agriculture and Health Sciences, 4(2),1-6.

Chaudhry, A. G., A. Ahmed, S. E. Khan \& S. Hussain. (2014). Perception of Local Community and Biradari on panchayat: An Exploratory Anthropological Study of Biradari in Village Saroki, District Gujranwala, Pakistan. Advances in Anthropology, 4, 53-58

Ekong, E. (2003). An Introduction to Rural Sociology. Uyo, Nigeria: Dove Educational Publishers.

Folger J. P., M. S. Poole \& R. K. Stutman. (2009). Working through Conflict Strategies for Relationships, Group and Organizations. USA: Pearson Education, Inc.

Galtung, J. (2006). Peace by Peaceful Means: Peace and Conflict, Development and Civilization. Sage Publication.

Glasius, M., Lewis, D., \& Seckinelgin, H. (Eds.). (2004). Exploring civil society: political and cultural contexts. Routledge.

Gyong, J. (2007). The Structure of Communication in Peace and Conflict Resolution, Identity, Crisis and Development in Africa. B. A. Celestine, Ed. Lagos. Malhouse Press.

Haider, Z., I. Jan and W. Akram. 2017. Effect of conflict on farmers' income from tomato crop in Kurram Agency, Pakistan. Sarhad Journal of Agriculture. 33(1), 171-176.

Haro, G. G. Doyo \& J. McPeak (2005). 'Linkages Between Community, Environmental, and Conflict Management: Experiences from Northem Kenya', World Development, 33 (2), 285-299.

Hejazi S. (2006). Sampling and its variants: Introduction to Research Methodology in Medical Sciences. Tehran: Islamic Azad University; 2006.

Iqbal, N. (2004, June 14-15). Affectees of Tarbela and Chotiari Dams: A struggle for social justice. United Nations Environmental Program. Addressing Existing Dams, Issue based workshop, Nairobi, (pp. 69-72).

Magsi, H., \& Torre, A. (2012). Social network legitimacy and property right loopholes: Evidences from an infrastructural water project in Pakistan. Journal of Infrastructure Development, 4(2), 59-76.

Maturo, A., E. Sciarraa \& A. G. S. Ventreb. (2010). Counselling: Decision Making Consensus, and Mediation. Procedia- Social and Behavioral Sciences, 5, 1770-1776

Mehmood, C. S., \& A. G. Chaudhry. (2015). Justice through Mediation: Revitalizing Informal Justice System. The explorer: Journal of Social Sciences, 1(4), 94-96.

Nformi, M. (2014). Effect of farmer-grazer conflicts on rural development: a socioeconomic analysis. Scholarly Journal of Agricultural Sciences. 4(3), 113-120.

Polit-0.,'Hara, D. \& C. T. Beck. (2006). Essentials of nursing research: Methods, appraisal, and utilization. 1. Lippincott Williams Wilkins; 2006.

Qu, Y., \& S. O. Cheung. (2014). Logrolling "Win-Win" Settlement in Construction Dispute Mediation: Springer International Publishing.

Robertson, A. \& O. Steve. (2012). Adapting Agricultural Extension to Peace building: Report of a Workshop by the National Academy of Engineering. USA

Roder, T. J. (2012). Informal justice systems: challenges and perspectives. Innovations in Rule of Law, 58.

Sabir, M., Torre, A., \& Magsi, H. (2017). Land-use conflict and socio-economic impacts of infrastructure projects: the case of Diamer Bhasha Dam in Pakistan. Area Development and Policy, 2(1), 4054.

Schellenberg, J. A. (2006). Conflict resolution. Theory, Research and Practice. State University of New York Press, Albany, NY.

Shinwari, N. A. (2015). Understanding the Informal Justice System: Opportunities and possibilities for legal pluralism in Pakistan. CAMP.

Siddik, M. A., M. A Rahman. \& M. Moniruzzaman. (2018). Causes and Consequences of Land Disputes in the 
Coastal Area of Bangladesh. Eastern Geographer, 24(2),7-15

Walker, S., C. Archbold, \& L. Herbst. (2002). Mediating Citizen Complaints Against Police Officers: a Guide for Police and Community Leaders. US
Department of Justice, Office of Community Oriented Policing Services Washington, DC

Yishai, Y. (2002). 'Civil Society and Democracy: The Israeli Experience. 13(3).

Publisher's note: EScience Press remains neutral with regard to jurisdictional claims in published maps and institutional affiliations.

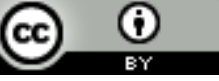

Open Access This article is licensed under a Creative Commons Attribution 4.0 International License, which permits use, sharing, adaptation, distribution and reproduction in any medium or format, as long as you give appropriate credit to the original author(s) and the source, provide a link to the Creative Commons license and indicate if changes were made. The images or other third-party material in this article are included in the article's Creative Commons license, unless indicated otherwise in a credit line to the material. If material is not included in the article's Creative Commons license and your intended use is not permitted by statutory regulation or exceeds the permitted use, you will need to obtain permission directly from the copyright holder. To view a copy of this license, visit http://creativecommons.org/licenses/by/4.0/.

(C) The Author(s) 2019 . 